\title{
The Implications of Land Tenure Systems on Socio-Economic Development in Kumbo Central Sub-Division, North West Region of Cameroon
}

\author{
Cordelia G. Kometa ${ }^{1} \&$ Richard N. Asongsaigha ${ }^{2}$ \\ ${ }^{1}$ Department of Topography and Real Estate Management, Higher Technical Teachers' Training College, Kumba, \\ University of Buea, Kumba, Cameroon \\ ${ }^{2}$ CCAST, Bambili, Bamenda, Cameroon \\ Correspondence: Cordelia G. Kometa, Department of Topography and Real Estate Management, Higher \\ Technical Teachers' Training College, Kumba, University of Buea, Kumba, Cameroon. E-mail: \\ ckgiven@yahoo.com
}

Received: September 1, 2019

Accepted: September 27, 2019

Online Published: September 30, 2019

doi:10.5539/jgg.v11n3p25

URL: http://dx.doi.org/10.5539/jgg.v11n3p25

\begin{abstract}
This study explores the impact of land tenure systems on the socio-economic development of Kumbo Central Sub-Division. The incompatibility of the Statutory and Customary land tenure and land laws in Kumbo brings about conflict between the land laws and land users at large. Land tenure insecurity and lack of land certificates are the major reasons for the slow growth rate in the socio-economic development of Kumbo. This study seeks to assess the reasons for tenure insecurity and implications on the socio-economic development of Kumbo. Data necessary for the realization of this study were obtained through primary and secondary data collection techniques such as questionnaires, interviews, field observation, focused group discussions, snap shorts and the review of related documented materials. These techniques followed a stratified sampling on an age selective population that was liable to have access to land. The study revealed that land ownership and land use conflicts emanate from poor and incompatible land tenure systems in Kumbo. The study recommended that the problem of incompatibility between the two tenure systems can be resolved by harmonizing the two laws. Also, the Social Tenure Domain System was recommended to solve the problem of land tenure insecurity if well implemented by the Government of Cameroon. This model enhances land tenure security for all, especially the vulnerable groups. If all these recommendations are implemented effectively, socio-economic development in Kumbo will be greatly accelerated.
\end{abstract}

Keywords: Incompatible Land Tenure Systems, Land Tenure Insecurity, Customary Law, Statutory Law, Socio-Economic Development, Kumbo

\section{Introduction}

Man as a social being has always made the decision to live where he could obtain his basic needs, but this is almost failing as man is faced with varied rules and regulations governing the ownership of land. Land is a very important resource for sustainable livelihood. According to Gerstter et al., (2011), land is a precious and a finite resource, thus, there are frequent struggles over access to land and how land should be used. It is a critical factor underlying relations of production between people. With this importance of land as a critical resource, there are bound to be rules and regulations governing its ownership. Land tenure is a tool for conservation and it involves a set of rules and regulations used to manage and control natural resources, such as soils, water and the environment (Bassey, 2010). Thus, land tenure brings about economic and social development. Land tenure issues are becoming increasingly important worldwide. Problems such as high population pressure, increase in resource degradation, food shortages, transformation of political systems and regional resource conflicts has brought the land issue to the public arena. Land tenure and land tenure systems are of fundamental importance for efficient agricultural production, stemming poverty and conflicts and attaining equity. Land is easily accessible to all agencies of development and requires the least combination of other factors of production and technology for exploitation. This easy access does not diminish the status of land as a critical determinant of well-being, livelihood, economic and political power (Hall, 1996). This means that land governance determines 
the distribution of wealth, influence and well-being. In other words, those who control land also control power (Lotsmart et al., 2013).

Inappropriate land policies constitute a serious constraint on economic and social development. On the one hand, insecure land tenure and dysfunction land institution discourage private investments and overall economic growth. On the other hand, skewed land ownership, distribution and discrimination according to gender or ethnicity limit economic opportunities for disadvantaged groups and provide fertile conditions for social conflicts, which usually erupt in violence (Economic Commission for Africa, ECA, 2009). Land tenure systems in the world have been a call for concern, especially that affecting the disadvantaged groups. This has called for international attention, and many international conferences such as Agenda 21, (UNCED-Conference in Rio, 1992), World Summit on Social Development (Copenhagen, 1995), World Women's Conference (Beijing, 1995), Habitat II Conference (Istanbul, 1996), and World Food Summit (Rome, 1996) which were held to address many issues including land tenure and related issues such as gender discrimination, land tenure insecurity, food insecurity, and land conflicts, amongst others.

Land tenure systems vary from one region to another. In the world today, especially in the more economically developed countries such as USA, statutory land laws has taken over customary land laws. The American Indians do not longer have great access to land as they did before the discovery of America by Britain. The concept of private property (land) right is an integral part of the legal structure of the European Society. The combination of private ownership and extensive individual rights has been the cornerstone of Western European and North American societies for the last two hundred years, to the point that they are commonly known as "property owning democracies" (Payne, 1996). With all these concerns about land in the world, there has been a need for land reforms. The coming of these land reforms has played a central role in the politics and the economy of many countries in the world and has been subject to massive disagreement between different political interest groups and ideologies. The $20^{\text {th }}$ Century included many of the largest social land reform experiments in history such as in the earlier Soviet Union, Eastern Europe, and China. Despite all these reforms, especially on Statutory land tenure, Customary land tenure remains a major world tenure system. Around two billion people today are customary land-holders in Africa, South-East Asia, Central Asia, Latin America, the Caribbean and the Pacific (Razavi, 2005). Their customary properties embrace over two billion hectares of land with a substantial proportion of this land made up of the forest or pasturelands.

Land policy formulation in Africa has escalated over the last ten years in response to the persistence of complex land problems, struggles for access to land for agriculture and livelihoods and to meet varied political, economic, social and environmental objectives. Rapid population growth, widespread poverty, persistent food insecurity and alarming rates of environmental degradation have fueled an increasing debate on land tenure systems and land reforms in Africa. Amin, (1972) says that most of the land tenure challenges facing Africa are legacies of the colonial period. In Africa, land is vital for poverty reduction, most rural households rely on it for survival, and most resource users gain access to land on the basis of local land tenure systems. These usually involve diverse combination of "statutory" and "customary" entitlements, and multiple and overlapping rights over the same resource (Cotula et al., 2007). In recent years in Africa, earlier emphasis on replacing "customary" with modern tenure systems has given way to the recognition that land policies and laws must be built on local practice. This replacement is cropping up as a result of major changes that have taken place in African economies and societies, including demographic growth, urbanization, monetarisation of the economy, livelihood diversification and cultural change (Food and Agriculture Organization, FAO, 2007). These processes have had major implications on local land tenure systems. In Francophone West Africa, only Senegal has implemented an extensive land tenure system reform in the past that strengthened the village community's land allocation and policies. "In general, reforms of land ownership in Africa have had less impact than those in Asia and Latin America (Kirk et al., 1999). Ofolla and Illugabe, (1996), opine that land tenure and its impact on economic and social development is not a recent phenomenon in Kenya and the whole of Africa. Prior to and after independence, radical changes have been deliberately initiated in tenure arrangements.

The land tenure system in Cameroon today is largely conditioned by systems which were established in the territory by successive European countries which administered what is now Cameroon. It began with Germany in the 1800s and ended with France in the 1900s (Ngwasiri, 2001). For balance argument, Britain also administered a smaller fraction of Cameroon between 1922 and 1961, but very little of the land laws which the British had introduced in British Cameroon had been retained in the present legislation. Thus, the word European is used to represent France. Cameroon authorities in borrowing the European concept on land ownership after Reunification in 1972 believed that it would promote the country's economic development. Before the European land concept and the 1974 Land Ordinances to regulate land ownership and registration, there has been 
traditional or customary land tenure which still exists today. In Cameroon, the statutory land laws exist alongside the customary land laws. Statutory law categorizes land in Cameroon into, national, state and private lands, while traditional or customary communities reclassify land differently into ancestral or communal, family land and individual land. All these different categories of land support development at different levels while some rather impedes development.

Land is a major factor of production and a source of livelihood in Cameroon. This is mainly because Cameroon is a strong agrarian society, where more than $80 \%$ of the population is engaged in agriculture, and the sector acts as a strong economic back bone of the country, hence, an impetus for development. The mid 2011 status of land reforms shows that Cameroon has no intention or is uncertain about coming up with a land reform (Liz Alden, 2012). Cameroon is a bi-jural country, which means that two different legal systems operate in different parts of the country. The French-oriented civil law applies in the eight eastern regions, and the English common law applies in the remaining two western regions (United State Agency for International Development, USAID, 2010). But the 1996 Constitution and 1974 Land Law apply nationally. The legal systems also recognize customary law which given the country's ethnic diversity, encompasses multiple and evolving traditional rules and norms. In Muslim regions, especially in the north, principles of Islamic law have been incorporated into customary law, although separate Sharia law is also recognized (Government of Cameroon (GOC) Constitution 1996; Fombad, 2009).

Kumbo like any other area in Cameroon and the world in general, strongly depends on land for socio-economic development. They are highly engaged in the cultivation of food crops such as maize, beans, potatoes, cassava, cow peace and huckle berry, among others; animal farming such as piggery, poultry, cattle and goat rearing. The Customary land tenure in Kumbo from time immemorial has always provided land for these purposes. This land tenure ensures that land for farming is given for free especially to the indigenes in their respective sub - ancestral lands (ngven). The produce from crop farming are used for the sustenance of the family, while the rest of the food crops together with the produce from animal farms is sold and the cash is used for education and for medical purposes. They also provide land for other developmental activities like schools and hospitals. This has been the major source of socio-economic development in Kumbo.

It is but obvious that land given to the ancestors for free, should also be handed freely to the descendants. But on the 6th of July 1974, President Amadou Ahijo, came up with ordinance No. 74-1, establishing rules governing land tenure in Cameroon and Kumbo in particular. This became the statutory land laws governing the ownership, transfer and development of land in Cameroon. Part two of the law constituting private property of Land Ordinance No. 74-1 of 6th July 1974; states that for any land to be legally recognized as private, group, community, company or State land, the land must be titled or backed up by a land certificate". This is supported by Decree No.76-165 of April 1976 to establish the conditions for obtaining land certificates, amended and supplemented by Decree No. 2005/481 of 16 December 2005, article one (1) which states that "The land certificate shall be the official certificate of real property rights". The Statutory land laws therefore created a tenure system based on "land registration" (USAID, 2010). This law had little or no recognition for Customary land laws. With the putting in place of Statutory rules governing land tenure in Cameroon, it became very clear that Statutory and Customary land laws govern land tenure in Cameroon and every developer is expected to strictly follow these laws before any improvement is made on the land. These laws have great impact on the socio-economic development of Kumbo.

\section{The Problem}

Man cannot do without the exploitation of the land for his livelihood, be it for shelter, farming, watershed and grazing, as well as for developmental purposes. But a problem arises, as man has to acquire the piece of land because of incompatibilities in the existing land laws in Kumbo. This incompatibility between the land laws bring about numerous conflicts, especially between the traditional authorities and administrative authorities, as they implement different laws on ownership and transfer of land. This ownership and land use conflicts are common in communal land where farmer-grazier conflicts, farmer-farmer and grazier-grazier conflicts seem unstoppable. Also, greedy individuals transforms part of the communal land to private land by obtaining land certificates. This is common when individuals after farming on communal land for long claims ownership of that portion of the land. This urges them to acquire land certificates from the government there by intensifying the problem. Furthermore, boundaries demarcation in communal land is not always effective because the boundaries change constantly given the fact that the land lord decides what portion of land to give to his subjects.

Land tenure insecurity is a major problem to the socio-economic development of Kumbo. Most people do not have land certificates, which is the only document that converts land to a legal private property. This tenure 
insecurity hinders heavy developmental projects from being carried out on these portions of land. Also, such unsecured lands cannot be used as collaterals, especially to obtain loans for further developmental projects. In case of demolition of buildings on such unsecured lands by the government as has been the case in the construction of the Bamenda-Kumbo High Way, little or no compensation is given to the owners. This greatly affects the socio-economic development of Kumbo, as heavy developmental projects are rarely carried without getting loans from the Banks or Credit Unions since they give out loans only to people with titled plots worth the transaction. Limited land certificates in Kumbo have greatly hindered the execution of developmental projects. Also plots in Kumbo without land certificates are usually liable to land conflicts and double crossing by land dealers. Such weaknesses are usually exploited by the rich to their advantage, as they are capable of obtaining land certificates. With such conflicts, these plots are usually laid fallow without being developed. These problems in Kumbo bring about several questions, which if well answered, will pave the path for socio-economic development.

\section{The Rearch Methodology}

The data necessary for the realization of this study involves two major sources, which include the primary and secondary data sources. Questionnaires, interviews and focused group discussion were the main sources of data collection. A stratified sampling method was used to administer the questionnaires, given the fact that population varies from one Sub-District to another, thus, the number of questionnaires for each Sub-District had to reflect its population. Samples of fifteen Sub-Districts in Kumbo Central Sub-Division were selected with a total population of 68,351 inhabitants. A sample base of 525 inhabitants was chosen. This implied that for every 525 people, one questionnaire was administered. About 130 questionnaires were designed and administered to the residence of Kumbo. This questionnaire was age selective, only to residents who were 25 years and above, since these age group had a better understanding of land and land issues. This provided information on the statutory and Customary Land Laws governing land ownership, and identified the indigenes who owned land with certificates, methods of acquisition, difficulties in obtaining land certificates, number of people who obtain loans from financial institutions and what they use as collaterals to obtain this loans, the relationship between unsecured land and impact on development. Valuable information on the traditional land laws, especially on the acquisition of land, transfer of land, as well as the operation of communal lands was gotten from the interviews and focused group discussion with traditional landlords. Also, information on inhabitant's reactions to statutory land laws and the socio-economic importance of statutory land laws to Kumbo were obtained from interviews with the Divisional Delegate of State Property, Surveys and Land Tenure and the Lord Mayor of Kumbo Council.

Secondary sources consulted provided data on how the Social Tenure Domain Model can be used to handle conflicts in land laws management. The Divisional Delegation of Land Tenure, Surveys and State Property, Delegation of Town Planning, Kumbo Council, and the Bui Court of First Instance provided documented materials such as the 1974 Ordinance on Land Tenure, procedures to obtain a land certificate, number of land certificates obtained by men and women from 2007 till present and the number of land dispute cases in the region. Both quantitative and qualitative techniques were used to analyse the data. Tables were used to present the data on the information on conflicting customary and statutory land laws. Bar graphs and pie were used to illustrate the various ways through which people get access to land and the various forms of collaterals in which land certificates and houses were the most valuable respectively.

\section{Land Tenure Systems in Kumbo}

Kumbo is the second biggest town in the North West Region of Cameroon in terms of population and socio-economic development. The indigenes of Kumbo attribute a lot of respect to their culture, and this respect is highly given to the Fon, and the Sub-Fons ("Shufais") who are believed to be the owners of Nso land. As a result, they have created non written laws which govern the ownership of land in Nso and Kumbo in particular. These non-written land laws have been termed Customary land laws. On the other hand, the statutory land law is fully represented in Kumbo which is the Administrative centre for Bui Division and a Central Sub-Division. With the Divisional Delegation of State Property, Surveys and Land Tenure, legal and written land laws are very visible in Kumbo.

\section{Customary Land Tenure}

Customary land tenure refers to unwritten land laws that are stipulated by Traditional rulers that guide and regulate land acquisition, ownership, use and transaction. In Kumbo, the Fon is believed to be the owner of all land in Nso. Due to the vast nature of the Nso land, the Fon cannot control all the land. Consequently, the Fon has given authority and power to Sub-Fons (shufais), clan heads (Fais) and Ardos for the Mbororos to assist him 
in land control matters. They are generally referred to as "Ta Mbvens" which means Land Lords. These traditional rulers strongly believe that they are the owners of land and follow Traditional or Customary laws in the distribution of land. The traditional rulers distribute land according to the use for which it is put in to. Field interview reveals that for land to be given for farming and housing, the people must have to follow different procedures. Land for farming is acquired through begging from the landlord which is given free of charge. When the land is obtained for farming, the farmer pays allegiance to the landlord after each farming season. This allegiance is usually done by giving a tin of corn to the Taa ngven. This loyalty is called "Nsu ngven". When the farmer is tired of cultivating the farm, the farm is taken back and given to a different person who is in need of a farm land. It is important to note here that farm land is rarely given for the cultivation of perennial crops such as plantains because the land can be taken away from the farmer at any point in time and need. Consequently, land is only given for the cultivation of seasonal crops such as corn, beans, potatoes, cow piece among others. Farmlands only become permanent for family members or clan members but they have no right to sell the land.

Customary land lords decide on what portion of the land to allocate to their subjects for farming and other developmental projects such as schools, water projects and hospitals. To obtain land for construction or housing requires a calabash of palm wine, a fowl, and firewood as pledge. When the land is given, the "Taa-ngven" initiates the foundation of the house known as ngwar kiseng. After the construction of the house, the "Taa-ngven" performs libations called "Ton vey". After that, the "Taa-ngven" plants a fig tree, known as "Kidzem" as well as a peace plant also known as "kikeng" which denotes the boundary of the land (Nyundini, 2014). It is important to note hear that when land is given to someone for construction, whether a family or a non-family member, it automatically becomes the persons personal land. On the contrary, land for grazing is handed out to potential graziers on temporal bases and a levy placed on them depending on the size of the grazing land. Initially, the grazier has to seek for the land with a calabash of palm wine and a fowl. Furthermore, the grazier gives a small financial token because of the profit making nature of the activity. This financial token does not mean that the land has been bought as it can be taken at any time especially when the grazier is not respecting the land laws. The Ardos act as an intermediary between the graziers and the land lord or "Taa ngven".

Under the Customary land tenure systems there exist sub-customary land tenure systems such as communal and family land tenure. In the Communal land tenure, a large portion of land exists strictly for the clan. This extensive portion of land is utilized for farming and grazing. Each individual born into this clan has the birth right to farm and graze on the land designated as communal land. In family land tenure, the family head, that is, the father of the house owns a large piece of land obtained from the clan head. This piece of land is strictly for the family. The women of the family, that is, the mother and the girl children have only use rights, and they cannot inherit this land if their husband or father dies. Only the male children have the birth right to inherit a portion of land after their father dies. Also, their father is obliged to allocate parcels of land to his matured male children to start off life with. This gives them individual ownership and use right over the piece of land.

\section{Statutory Land Tenure}

Statutory land tenure refers to written legal land rules and regulations governing the acquisition, ownership, use and transfer of land. Statutory land tenure is identified with colonialism because it was initiated by the colonial masters in Cameroon. This land tenure system in Cameroon has little or no difference from what the colonial masters initiated especially the French. Prior to the independence of French Cameroon in 1960, and British Cameroon in 1961, and their later reunification in 1971, the then president of Cameroon Ahmadou Ahidjo, came out with Ordinance $\mathrm{N}^{\circ} .74-1$ of 6 July 1974 to establish rules governing land tenure. These rules which still exist today and are highly applicable in Kumbo are sub-divided into four parts such as General Provisions, Private Property, National Lands, and Taxation of Landed Property.

Article 1 which constitutes part one of the general provision states that the state guarantees to all natural persons and corporate bodies having landed property the right to freely enjoy and dispose of such lands, the state shall be the guardian of all land and may in this capacity intervene to ensure the rational use of land or in the imperative interest of defense or the economic policies of the nation and the terms and conditions of such intervention shall be fixed by decree. Article 2 constituting part two strictly dwells on private property. Here, the following categories of lands shall be subject to the right of private property; registered lands, freehold, lands acquired under the transcription system, lands covered by a final concession and lands entered in the grundbuch. Article 6 and 7 of this law states that the applications for land certificates and certificates of occupancy in progress on the date on which the present ordinance enters into force shall proceed to completion in accordance with the regulations in force and the terms and conditions of issue of land certificates, and the rules relating to the cancellation of the same, shall be fixed by decree respectively. 
Article 8 states that the same penalties of 25,000 - 100,000FCFA or with imprisonment of 15 days to 3 years, or with both shall apply to persons selling or leasing one and the same land to two or more persons and persons effecting sales or leases of lands belonging to others not being empowered. Article 13 stipulates that the bodies on whose behalf expropriation is applied shall compensate the dispossessed persons from their budget and no compensation shall be payable for the destruction of dilapidated building liable to collapse, or building erected contrary to town planning regulations. Article 14 which falls under part III constitutes the national lands. It is stated that national lands shall as of right comprise lands which, at the date on which the present ordinance enters into force, are not classed into the public or private property of the state and other public bodies. National lands shall not include lands covered by private property rights as defined in Article 2a above. Article 15 states that these lands shall be divided into two categories, that is, lands occupied with houses, farms and plantations and grazing, lands manifesting human presence and development and lands free of any effective occupation. Article 16 states that national lands shall be administered by the state in such a way as to ensure rational use and development thereof and that consultative boards presided over by the administrative authorities and necessarily comprising representatives of the traditional authorities shall be established for this purpose. Article 17 states that national lands shall be allocated by grant, lease or assignment on conditions to be prescribed by decree.

Article 19 constituting Part IV is centered on taxation on landed property. It states that the establishment of land certificates, miscellaneous entries in the land register and the issuance of statements of entries in the land register of miscellaneous certificates at the request of corporate bodies, topographical, topometric and surveying work shall be subject to the collection of fees. The rates of such fees shall, where applicable be fixed by the Finance Law. This Statutory land laws are implemented by the Divisional Delegation of State Property, Surveys and Land Tenure. The inhabitants of Kumbo have little or no idea about these laws. The highest law that is greatly implemented in this region is that of land certification. This brings about conflict and incompatibility in the different land laws with so much implication on socio-economic development.

\section{Incompatibility between Statutory and Customary Tenure Laws in Kumbo}

Statutory and Customary land laws existing in Cameroon in general and Kumbo in particular are highly incompatible. From field evidence, it was established that the Statutory land laws are legal and well written down while the Customary land laws are illegal and not written down. Based on the statutory land laws, the state only recognizes land that is registered and backed by a land certificate. While according to Customary law, a recognized parcel of land is that officially handed to the owner by a "Taa' ngbven". Under Statutory land laws, a piece of land is officially demarcated by a pillar, while in the Customary land laws, a piece of land is officially demarcated by "Kidzem", that is, a fig tree or by "Kikeng" (piece plant). Conflicts between Statutory lands as well as Statutory and Customary lands are resolved in the Bui Court of First Instance, while conflicts between Customary lands are resolved in the Nso Fons Palace. Statutory land laws go with a lot of financial spending while Customary land laws require little or no financial spending. Figure 1 presents the Traditional and Statutory pillars for boundary demarcation.

Field evidence also proves that there are controversies with respect to what these two land laws represent. Customary landlords want their laws on land to be scrupulously followed as the original laws of the land. On the other hand, the administrators of the Statutory land laws opine that no other land laws exist in the country apart from the Statutory. This incompatibility between the Customary and Statutory land laws greatly impedes the socio-economic development of Kumbo (Table 1).

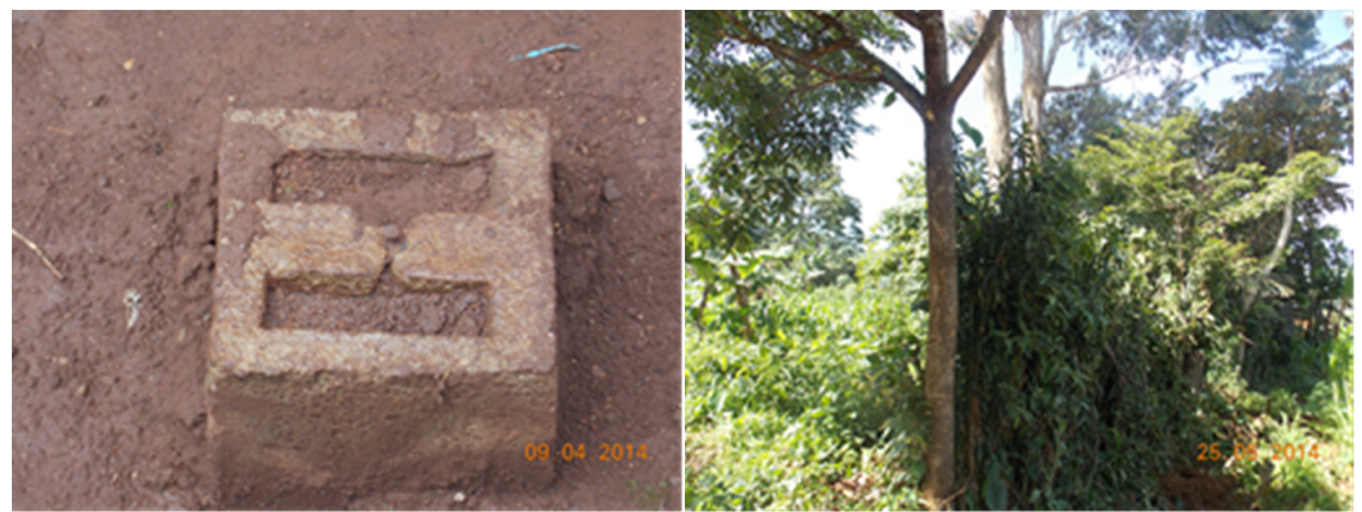

Figure 1. Legally recognized Statutory pillar with the Fig tree and peace plants representing traditional land pillar (Field work, 2014) 
Table 1. Characteristics of Information obtained on the Statutory and Customary Land Laws

\begin{tabular}{|c|c|c|c|c|}
\hline \multirow{3}{*}{$\begin{array}{l}\text { Characteristics } \\
\text { Do you know of any land laws that govern the } \\
\text { ownership of land in Kumbo }\end{array}$} & \multicolumn{4}{|c|}{ Frequency of information acquired } \\
\hline & YES & NO & & \\
\hline & 121 & 02 & & \\
\hline \multirow{2}{*}{ Name the land laws you know } & Customary & Statutory & \multicolumn{2}{|l|}{ Statutory and Customary } \\
\hline & 81 & 15 & 25 & \\
\hline \multirow{2}{*}{ Are these laws properly implemented } & YES & NO & & \\
\hline & 19 & 102 & & \\
\hline \multirow{2}{*}{$\begin{array}{l}\text { Do Traditional land laws conflict with State } \\
\text { land laws }\end{array}$} & YES & NO & & \\
\hline & 119 & 02 & & \\
\hline \multirow{2}{*}{$\begin{array}{l}\text { Does these conflicts affect the socio economic } \\
\text { development of Kumbo }\end{array}$} & YES & NO & & \\
\hline & 119 & 02 & & \\
\hline \multirow{2}{*}{ Are there land ownership conflicts } & YES & NO & & \\
\hline & 119 & 02 & & \\
\hline \multirow{3}{*}{$\begin{array}{l}\text { What are the causes of these land ownership } \\
\text { conflicts? }\end{array}$} & Poor land tenure & Corrupt & Increasing population & Greedy \\
\hline & laws & administ-rators & and land scarcity & tradition-al rulers \\
\hline & 78 & 14 & 15 & 12 \\
\hline
\end{tabular}

Source: Field work, 2014.

From Table 1, 98.4\% of the population has some knowledge about land laws existing in Kumbo. Out of this knowledgeable population, $66.9 \%$ of the population is verse only with Customary land laws, while $12.4 \%$ is conversant with Statutory land tenure and $20.7 \%$ is verse with both Statutory and Customary land Laws. From this statistics, it becomes very evident that the customary land tenure is the most popular in Kumbo Central Sub-Division, as indicated by $87.8 \%$ of the sample population. The unpopular statutory land tenure system is considered legal and must be respected and implemented by the inhabitants on a daily basis. This is a source of conflict between the two land laws which retards the socio-economic development of Kumbo. The ignorance of the indigenes about the Statutory land laws has led to the extortion of large portions of land from them leading to ownership conflicts. With such conflicts, the land remains fallowed, for a long time with little or no developmental projects. Some of these conflicts are a result of the fact that "Traditionally, land can be transferred from one person to another by way of gift or inheritance without the need of any written document" while for the Statutory land laws, transfer documents must be issued". Over $98.3 \%$ of the sample population confirms the fact that conflict between these land laws is adversely affecting the socio-economic development of Kumbo.

\section{Land Tenure Security in Kumbo Central Sub-Division}

Land tenure security is a strong prerequisite for the socio-economic development of Kumbo. Secured access to land reduces vulnerability to hunger and poverty. With land being totally secured, it gives the owner a strong incentive to invest on the land. This enhances developmental activities such as construction for residential or business purposes, large scale farming activities, leasing and livestock keeping amongst others. Land tenure security in Kumbo is in many forms, such as the traditional land that is well recognized, inherited land, purchased land well known by neighbours and other witnesses as well as titled land backed up by land certificates and pillars. All these forms vary in their level of security, with the highest secured land being that with a land certificate and pillar.

\section{Access to Land and Security}

Access to land in Kumbo is of different categories. Land as a vital resource in Kumbo is used for agricultural activities, especially food crop production, the construction of infrastructures for business and residential purposes, as well as for leasing and selling. This vital nature of land explains why $88.6 \%$ of the sample population had access to land which is either through customary or statutory land laws. Land for these various activities is acquired through different means (Figure 2).

Figure 2 illustrates that many people in Kumbo do not have access to permanent land, as $17.4 \%$ of those that have land cannot claim total ownership of the land since it is either rented or begged. In addition, $11.4 \%$ of the population does not have a piece of land at all. It is not easy to have access to permanent land in Kumbo because following the customary land tenure, land is mostly acquired by inheritance. This is justified by the fact that over $32.20 \%$ of the population with a piece of land acquired it through inheritance. While following the statutory land laws, land is highly purchased. Over $39.4 \%$ of the population owns a piece of land through purchase. The 
population that has no land at all as well as those who cannot lay total claims to a piece of land made it clear that the reasons why they cannot claim land ownership is as a result of the expensive nature of land, scarcity of land and discrimination especially the women by tradition.

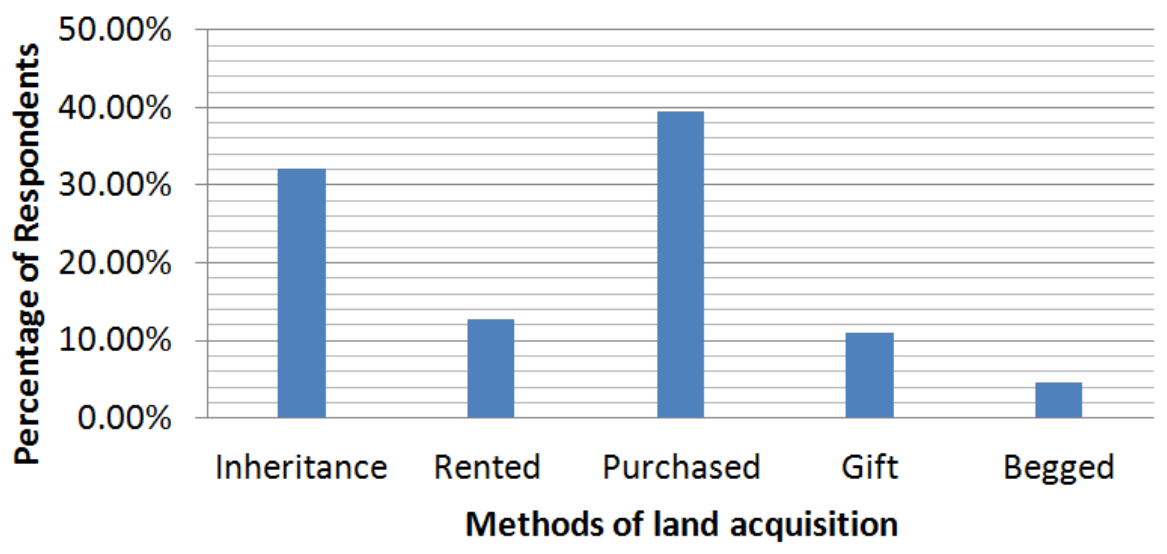

Figure 2. Methods of Land Acquisition in Kumbo (Field work, 2014)

These difficulties of obtaining land or claim total ownership to a piece of land in Kumbo greatly hinder them from carrying out socio-economic activities. The planting of perennial crops like plantains and coffee that generates a lot of revenue and consequently, increasing their standard of living cannot be cultivated on insecure lands. Due to the powers traditional rulers have over land, $11 \%$ of the sampled population having land testified that the land was acquired as gifts, especially from the traditional authorities "Taa ngven". It has been realized that more often than not, those that own land through gifts or inheritance cannot carry out developmental projects that could enhance the socio-economic development of Kumbo.

\section{Challenges in Obtaining Land Certificates in Kumbo}

Following Ordinance $\mathrm{N}^{\circ} .74-1$ of 6 July 1974 to establish rules governing land tenure, part II article 7 ordained that the terms and conditions of issue of land certificates and the rules relating to the cancellation of the same shall be fixed by decree. Based on this, Decree No. 76-165 of April 1976, conditions were established for obtaining land certificates. This decree had a lot of short comings as the time taken to issue a land certificate was too long, sometimes more than two years. Also, the procedures to follow were just unbearable and not well outlined. These short comings brought about Decree No. 2005/481 of 16 December, 2005 to amend and supplement the former Decree. On paper this new decree for obtaining land certificates brought about the following innovations; the procedure for obtaining land certificate has now been simplified, the time limit for obtaining land certificates reduced considerably as one can obtain his land certificate in 6 months, the procedure for obtaining a land certificate has been decentralized. It now starts at the level of the Sub-Division and end at the level of the Region in case there is no opposition. And the decision to settle disputes was now signed by the Governors and no longer the Minister of State Property, Surveys and Land Tenure.

Article 1 of No. 2005/481 of 16 December 2005, ordains that "The land certificate shall be the official certificate of real property rights". Without a land certificate, one cannot claim total ownership of land in Kumbo. The Divisional Delegate of Land Tenure even quoted that "land certificates act as the birth certificate of the land'. The question now is whether it is easy to obtain a land certificate. Figure 3 presents the number of the sampled population that has land with certificates in Kumbo. Land certificates have a strong incentive on property development. 


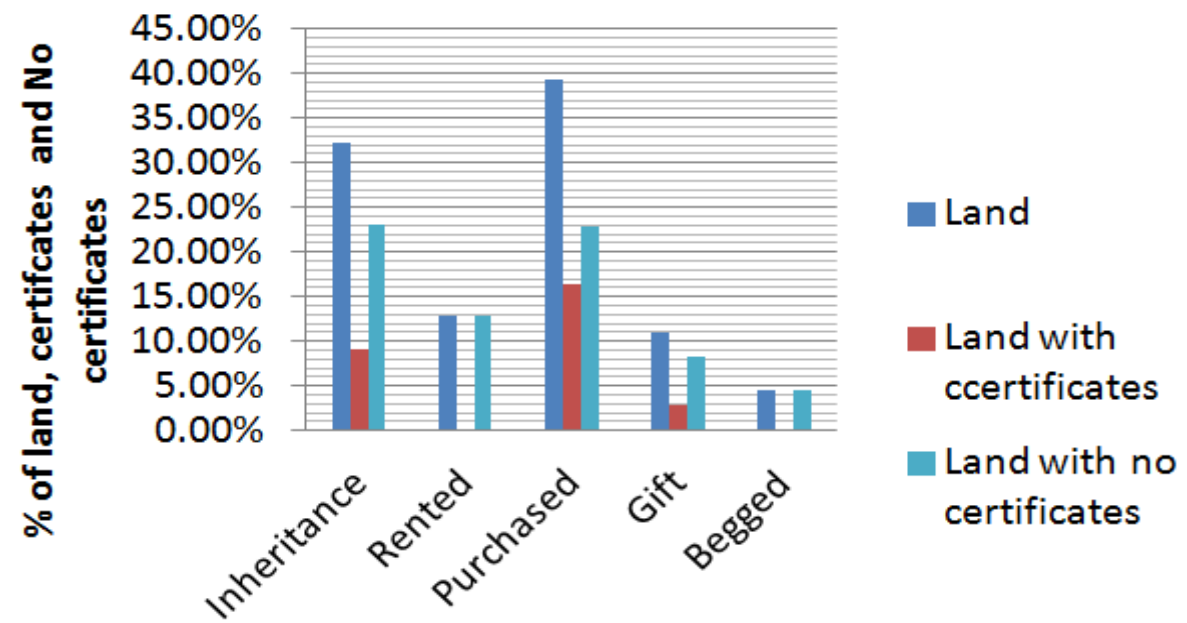

Methods of land acquisition

Figure 3. Portions of land with and without land certificates in Kumbo (Field work, 2014).

Figure 3 shows that only $28.4 \%$ of the sampled population has lands with land certificates while $71.6 \%$ have no Land certificates. Most of these land certificates were highly obtained by those who acquired their land through purchase, that is, $16.5 \%$, while $9.2 \%$ of the land certificates were obtained by those that acquired land through inheritance and $2.8 \%$ of the land certificates by those that acquire land as a gift especially from the Traditional rulers. This low number of land certificates in Kumbo is a result of the fact that the process of obtaining a land certificate is very expensive with a lot of hierarchy to be followed. There also exists corrupt land administrators and inadequate information. All these reasons made majority of the respondents without land certificates to declare that they were not interested in obtaining the certificate. Even those that testified to have land certificates complaint that it was not easy for them to obtain them as the procedure was too long with a lot of hierarchy, discrimination and exploitation involved.

Following Decree No. 2005/481 of December 2005 to simplify the procedure to obtain land certificates on National Land of the $1^{\text {st }}$ Order through direct registration, the supposed simplified procedure has more than 14 stages. The first stage is filling an application form and depositing it at the Divisional Office, where the Divisional Officer (DO) issues a custody receipt within 72 hours in respect to the application. This application is now transmitted within 8 days to the competent Divisional Delegation of State Property, Surveys and Land Tenure. Other 12 stages then take place such as verification of effective date of occupation, publication of a public notice to expire after 30 days, meeting of Consultative Board and Commission, demarcation exercise, plans and cadastral reports among others. It is only after these procedures that the Divisional Delegate of State Property, Surveys and Land Tenure forwards the complete file to the Regional Delegation of State Property Surveys and Land Tenure. It is at this stage that the Regional Service of Land Tenure gives the file a number. After examination, if the file is regular, it is then endorsed or approved for final demarcation by the Regional Chief of Service for Land Tenure. These files that are approved are then sent back to the Divisional Delegate of this sector for the establishment of land certificates by the Land Registrar in the event where there is no objection.

Apart from this very long procedure, the State says that "It is the sole responsibility of the individual in search of the land certificate to take care of Logistics" (MINDAF, 2008). The question again is what are logistics, what amount, how many items are in this logistics? This is where problems set in and make this aspect of obtaining land certificates a mystery for the poor. Financially, before your file is attended to, you must pay a survey fees of 30,500 FCFA, 10,000FCFA to Land Tenure, Commission fees directly to the D.O, 100, 000FCFA, and 2500FCFA for each Pillar. Logistic is to be catered for by the person in pursue of land certificate. It is important to note here that the commission is made up of Surveys, Land Tenure, MINADER, MINDU, Fon's representative and the D.O who is the chairman of the commission. The head of the consultative commission has been given rights by the Minister of MINDAF to fix reasonable fees to be payed to the consultative board to assess a piece of land for the time being (MINDAF, 2008). This amount is too much for the rural poor and many others living on average bases. First of all, the amount is not fixed and well outlined and this amount could even increase depending on the size of the plot and distance between the land and the local MINDAF service. A 
respondent declared that he spent more than 211,000FCFA to meet up with the procedures for obtaining a land certificate for a small plot and at the time he does not even know when the certificate will be issued. This brings to light that even those that struggle to obtain the land certificates are not comfortable with the procedures and the expenses. This difficulty in obtaining land certificates is well x-rayed in Table 2, representing the number of land certificates obtained in Kumbo from 2007 to 2013 by both women and men.

From Table 2, a total of 499 land certificates were issued between 2007 and 2013. Over 97.2\% of the land certificates were issued to men and only $2,8 \%$ were issued to women. This simply supports the fact that in addition to the expensive and tedious process in obtaining land certificates, there is a lot of gender discrimination, with men greatly favoured to the detriment of women. This reduces the number of land certificates in Kumbo. Also, verification from the Delegation made known the fact that most of the people who have land certificates in Kumbo are resident out of Kumbo in towns such as Douala, Yaoundé, Bafoussam, and Bamenda. They do this in other to secure their lands as they are not around.

Table 2. Number of land certificates obtained in Kumbo from 2007 to 2013

\begin{tabular}{llll}
\hline \multirow{2}{*}{ Year } & \multicolumn{2}{l}{ Number of Land Certificates Obtained } & Total \\
\hline 2007 & Men & Women & 59 \\
2008 & 58 & 01 & 73 \\
2009 & 71 & 02 & 72 \\
2010 & 71 & 01 & 75 \\
2011 & 75 & 00 & 79 \\
2012 & 76 & 03 & 60 \\
2013 & 57 & 03 & 81 \\
TOTAL & 77 & 04 & 499 \\
\hline
\end{tabular}

Source: Delegation of State Property, Surveys and Land Tenure, 2014.

\section{Impact of Customary Land Tenure on the Socio-Economic Development of Kumbo}

Customary land tenure has played a very positive role in the socio-economic development of Kumbo. This is because the landlords are wiling at all times to allocate land for developmental activities when need be. For instance, it was the Customary land laws that accelerated the construction of two reputable hospitals in Cameroon, that is, the St Elizabeth General Hospital Shisong-Kumbo and the Banso Baptist Hospital, Kumbo. The land on which these hospitals were built was offered for free by the then Fon of Nso, and his assistant (Shufais). These hospitals brought a lot of development in Kumbo through the enhancement of the health of the Kumbo inhabitants and Cameroonians in general. These hospitals have created thousands of job opportunities for the inhabitants of Kumbo and Cameroonians as a whole. These hospitals act as a pull factor attracting many personnel including non-indigenes in to Kumbo. These hospitals have triggered other developmental activities such as petite businesses like store, food sellers as well as workers in different domains. This brings in a lot of income that is spent in developing other sectors of the economy. Increase in income levels reflects in the standard of living of the people.

Besides the provision of land for hospitals, the Fon of Nso and his Shufais equally allocated free land in Melim-Ngankichi for the construction of Higher Institutes of Learning such as the Faculty of Health Sciences of the Catholic University of Cameroon (CATUC) in Kumbo, the St Augustine's College Nso and Government Bilingual High School, Kumbo. This university and the colleges have brought in rapid socio-economic development in Kumbo. With the construction of the university campus in Melim, a lot of developmental activities have been greatly accelerated. Figure 4 illustrates developmental projects accelerated by Customary land tenure in Kumbo. The construction of the Bamenda-Kumbo Ring Road led to an increase in the influx of population into Kumbo, hence, further developmental activities.

Many developers in Kumbo have acquired pieces of land around this university campus for the construction of student hostels and other developmental activities like retail stores, documentations and hair dressing saloons amongst others. The university offers employment to many people in Kumbo as well as the growth in infrastructural development. The role played by Customary land laws in enhancing development through land allocation can therefore not be over emphasized. 

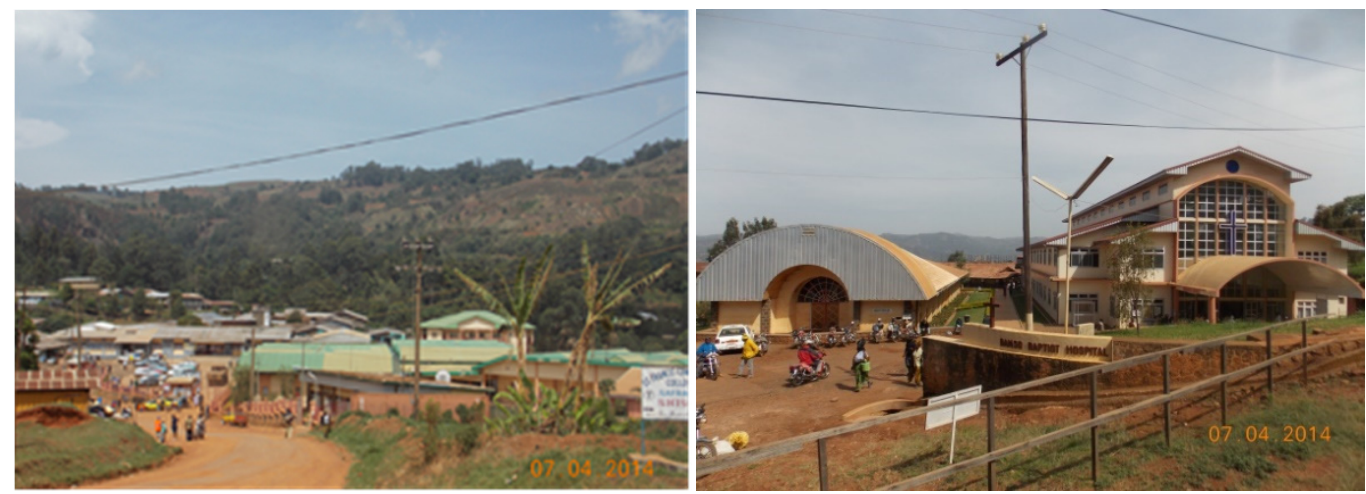

Figure 4. The Shisong General Hospital and the Banso Baptist Hospital respectively (Field work, 2014)

Although the Customary land tenure has been very instrumental in enhancing the socio-economic development of Kumbo, they are not without negative setbacks. The Customary land tenure in Kumbo does not allow women to own land. This greatly discourages them from carrying out heavy developmental projects such as intensive agriculture and infrastructural construction since the land can be seized from them at any moment. With the advent of globalisation, there are a lot of women in government who can initiate developmental activities in the region more than men but because they are restricted from owning land, development is handicapped. Thus, if these laws are revisited it will go a long way to enhance development. Furthermore, the customary land tenure does not easily allow non-indigenes to own land in Kumbo. They preserve large portions of land for their future generations through inheritance. It is true that rapid development in any location is an indication of the presence of non-indigenes in the area. This discouragement of the non-indigenes from carrying out developmental projects in Kumbo especially infrastructural development is the main drawback for socio-economic development. The income generated by these non-indigenes in Kumbo is therefore invested elsewhere.

\section{The Role of Land Certificates in the Socio-Economic Development of Kumbo}

Following the Statutory land laws, Article 1 of Decree No. 2005/461 of 16 December, 2005 is the most striking and important law. This law states that "Land certificates shall be the official certificate of real property rights". So, a land certificate is a strong tool in the Statutory land law as it commands a lot of legal backings. Land certificates play a very positive role in the socio-economic development of Kumbo. The $28.4 \%$ of the respondents with land certificates and $52 \%$ of the respondents with no land certificates agreed that land certificates enhance the socio-economic development of Kumbo. This is as a result of the fact that Land certificates provide security to the land owners making giant developmental projects like huge residential properties for business purposes, intensive farming and renting or leasing feasible. This is the case of Confidence Business Structure and the John Paul II Youth Center in Tobin, the Shiyka and Promise Super Markets in Mbveh with fantastic structures, as well as Mary Land, Fomo and Ice Breakers hotels in Kumbo (Figure 5). These types of great structures can only be constructed on secured portions of land. These business centers do not only improve on the aesthetics of Kumbo but also employs many youths, thereby helping them to improve their living standards.

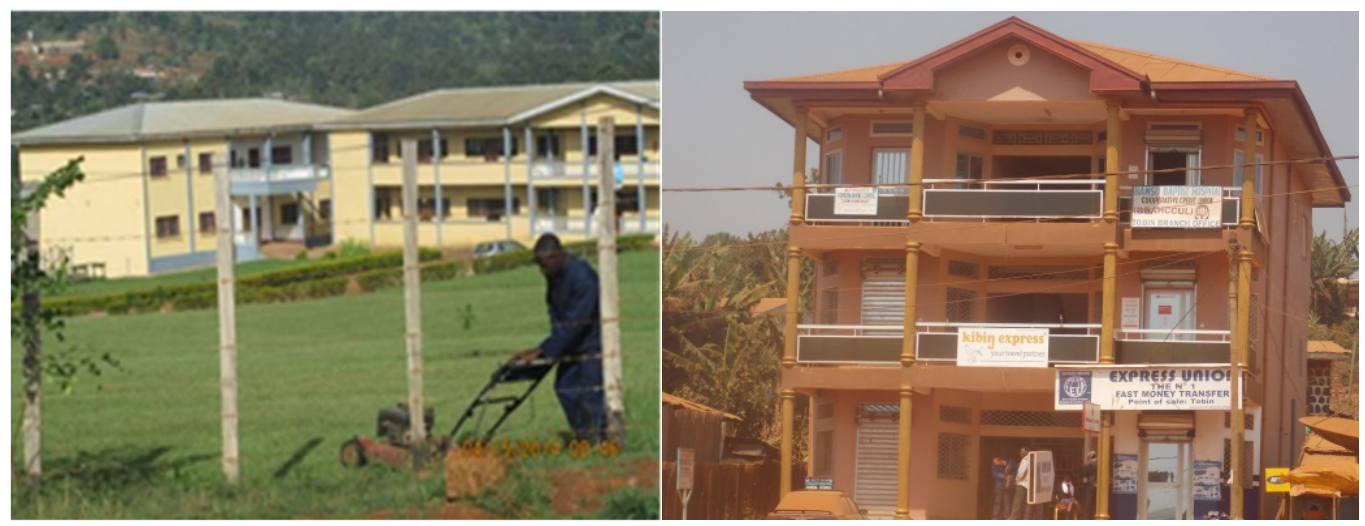

Figure 5. John Paul II Youth Center and Confidence Multi-Business Center in Tobin (Field Work, 2014) 
In addition, land certificates are used as collaterals to obtain loans from financial institutions like the Union Bank of Cameroon and the Mbveh Police Credit Union. These loans aid in carrying out other developmental projects especially when investing in large businesses. Over $75.6 \%$ of the sampled population accepted that they used these properties to obtain loans while $24.4 \%$ do not. It is evident that individuals might not have steady money to carry out huge developmental activities. For such projects to be realised, they need loans from banks which can only be achieved through collateral security. In an emerging town like Kumbo, this collateral is mostly in the form of lands or buildings. These properties cannot be used as collaterals without land certificates. As a result, it becomes very difficult to obtain loans for developmental projects, hence, slow rate of socio-economic development. Land certificates have been of great importance in achieving heavy developmental projects in Kumbo. Figure 6 illustrates the various collaterals used by the developers to collect loans.

\section{Collaterals}

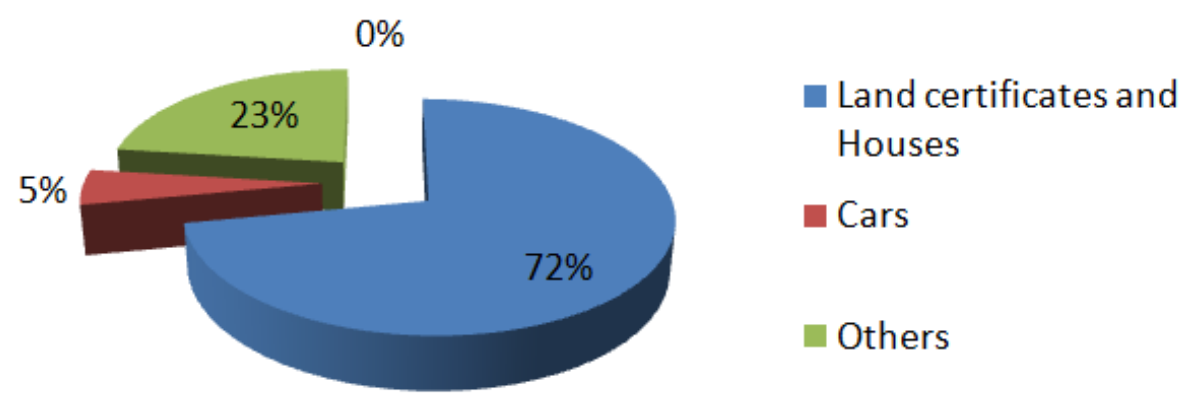

Figure 6. Collaterals used in obtaining loans from financial institutions (Field work, 2014)

Figure 6 shows that $72 \%$ of the sampled population used land certificates and houses as collaterals to obtain loans for further developmental activities. Also, $5 \%$ of the respondents use cars as collaterals, $23 \%$ used other forms of collateral such as salary, shares and sureties to obtain loans. Field evidence has proven that land certificates are very instrumental in obtaining loans because they add value to land. The Delegate of Land Tenure testified that someone can borrow his land certificate to another person to obtain a loan. Land certificates also add value to land because the state is up large to negotiate with land owners in times of expropriation and lands with certificates are free from land conflicts as they are legally backed up by law. This greatly motivates land owners to exploit their usufruct rights to the later, consequently, development.

On the other hand, due to the long procedure and the expensive nature of obtaining land certificates as well as gender discrimination, very few people have land certificates in Kumbo. This makes the inhabitants to be vulnerable because land without any legal backing is susceptible to conflicts. Also, lands not backed by land certificates have limited access to loans because they cannot be used as collaterals. Additionally, in times of expropriation, the government does not negotiate with people that have land with no certificates. Field evidence justifies the fact that land with no certificate brings about unclear and overlapping land rights and insecurity of farmers. As a result, socio-economic development is being handicapped since land under conflicts cannot be developed. Without financial assistance such as loans, large businesses and developmental projects cannot be carried out. Also, insignificantly compensated expropriated structures greatly slow down the socio-economic development of Kumbo. Figure 7 illustrates expropriated structures and an untitled land with structures liable to expropriation in Kumbo. 


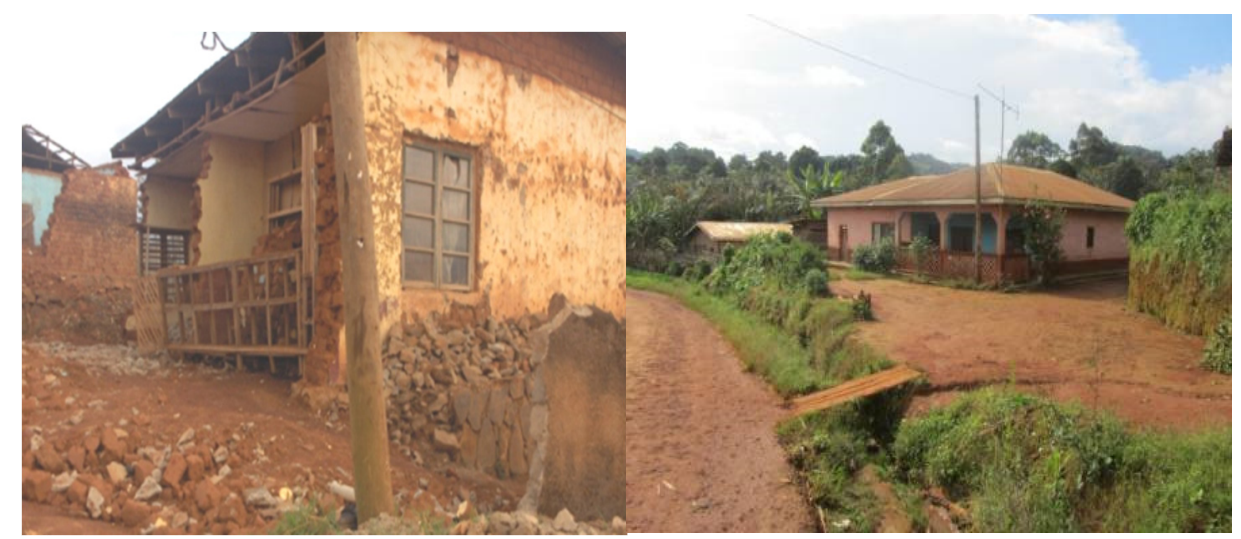

Figure 7. Expropriated structures and untitled land with structures liable to expropriation (Field work, 2014)

Figure 7 presents the demolition of structures constructed beside the road side. The owner of this land had no land title, hence, cannot be compensated by the Government. The untitled land with structures liable to expropriation is as a result of the fact that construction does not respect the town planning norms stating that buildings should be constructed 20meters away from the middle of a primary road and 15 meters away from the middle of a secondary road. With this, these structures are liable to expropriation with little or no compensation from the government, mainly because these lands do not have land certificates. This is backed by part two, Article13(2) of the 1974 Land Ordinance, which ordains that "No compensation shall be payable for the destruction of dilapidated building liable to collapse, or building erected contrary to town planning regulations." The increase in expropriation stems out from the construction of the Bamenda-Kumbo Highway that cut many people along the line. These are impediments to the socio-economic development of Kumbo because in addition to the fact that structures are demolished, people without land certificates are strongly discouraged from carrying out developmental activities especially construction beside road sides.

\section{The Blue Print}

Land tenure systems and land tenure security plays important roles in the enhancement of socio-economic development. So in order to ensure that sustainable development is attained in Kumbo, these land laws needs to be harmonized and effectively implemented. Traditional rulers should be made to understand that after the Land Ordinance of 1974, all land became National land and controlled by the State. As a result, they are only the custodians and not owners of the land. This will set the way for harmony and consequently socio-economic development in Kumbo.

The inhabitants of Kumbo should be strongly sensitized through the local medium such as the Bui Community Radio, Radio Avagelium, Bui City Radio and Helen Kris Radio on the Statutory land laws and its importance in socio-economic development. This sensitization will encourage many inhabitants to go in for land certificates, which in turn will motivate developmental projects. In the context of property development, no property can be developed without the legal description of the land. If this property is not legally described, it cannot be issued a land certificate. As a result, the development of giant projects that can bring in a lot of socio-economic development cannot be feasible without security.

A well outlined and straight forward procedure for the acquisition of land certificates should be instituted with fixed amount of money payable to obtain the land certificate. This will reduce the exploitation of the masses during the process of acquiring land certificates and therefore encourage many inhabitants of Kumbo to obtain their land certificates. The Statutory and Customary land laws should be harmonized through a land reform which will go a long way to reduce land ownership conflicts in Kumbo, thus, paving the way for the socio-economic development of Kumbo. This can be achieved if the government of Cameroon should implement the Social Tenure Domain Model, by developing or buying the software that will be used in all areas to register individual land without any rate to be payed. With this, everybody having a piece of land, both the poor and the rich will have their land registered and legally recognized through their finger prints and photographs. This will bring about land tenure security which is a motivating strategy for socio-economic development.

\section{Conclusion}

Land tenure systems vary from one region to another. This variation has an impact on the socio-economic development of that region. Where ever these land tenure systems abound, socio-economic development can 
only be enhanced through careful reformation of the land tenure systems. The incompatibility of the Customary and Statutory land tenure of Kumbo, their poor implementation and land tenure insecurity brings about land ownership conflicts with negative implications on socio-economic development. This insecurity is caused by the unbearable conditions in obtaining land certificates, gender discrimination and expropriation of land and infrastructure by the government. The socio-economic development of Kumbo can only be enhanced if these problems are brought under control.

\section{Conflict of interests}

The authors declare that there is no conflict of interests regarding the publication of this paper.

\section{Reference}

Amin, S. (1972). Neocolonialism in West Africa (p. 2). Hammondsworth, U.K.

Bassey, E. (2010). Land Tenure and Sustainable Management of Agricultural Soils. Center for Development and Environment, Bern.CI

Cotula et al. (2007). Changes in Customary Land Tenure Systems in Africa. Earth Print- UK

Economic Commission for Africa. (2009). Land Tenure Systems and their Impact on Food Security and Sustainable Development in Africa (2nd ed.). ECA Print Shop Addis Ababa.

FAO. (2007). In L. Cotula (Ed.), Changes in “Customary” Land Tenure Systems in Africa.

Fombad, C. M. (2009). Update: Researching Cameroonian Law. Globalex-Cameroon.

Gerster, T., Van, F., \& Guusvan, W. (2011). Investors in Land; Perspectives on Investors Engaged in Transitional Land Acquisition in Developing Countries. European Report in Development.

Government of Cameroon. (1996). Ordinance No. 74-1 of 6th July 1974: To establish rules governing land tenure in Cameroon, Modified by Ordinance No 77-1 of 10th January 1977.

Liz Alden, W. (2009). Customary Land Tenure in the Modern World: Rights to Resource in Crises. Ford Foundation.BRILL.

Lotsmart, F., Fombe, L., \& Samalang. (2013). Land Tenure Practices and Women`s Rights to Land in Anglophone Cameroon: Implications for Sustainable Development. International Development Research Centre (IDCR).

MINDAF. (2005). One Hundred Questions of the User. A Publication of MINDAF.

Ngwasiri, C. N. (2001). European Legacy of Land Legislation in Cameroon. In Readings in Geography, 1(1), 341-348.

Nyuydini, R. N. (2014). The Impact of Land Tenure Systems On The Socio-Economic Development Of Kumbo Central Sub-Division, North West Region, Cameroon Undergraduate DIPET II Project. Department of Geography, ENS Bambili, The University of Bamenda.

Payne, G. (1996). Urban Land Tenure and Property Rights in Developing Countries: A Review of the Literature.

Razavi, S. (2005). Land tenure reform and gender equality, UNRISD, Geneva. Sengupta, Town 1998, 147-159.

USAID. (2010). Cameroon Property Rights and Resource Governance. USAID Country Profile.

\section{Copyrights}

Copyright for this article is retained by the author(s), with first publication rights granted to the journal.

This is an open-access article distributed under the terms and conditions of the Creative Commons Attribution license (http://creativecommons.org/licenses/by/4.0/). 